\title{
Comparative Study on Histopathological Changes caused by Meloidogyne enterolobii in Psidium gujava and Psidium cattleianum Guava Species
}

\author{
Gummadi Sreekavya', I. Muthuvel ${ }^{2}$, J. Rajangam ${ }^{1}$ and S. Prabhu ${ }^{3} *$
}

${ }^{1}$ Department of Fruit Crops, ${ }^{3}$ Department of Spices and Plantation Crops, Horticultural College and Research Institute, Tamil Nadu Agricultural University, Periyakulam, India

${ }^{2}$ Horticultural Research Station, Kodaikanal, India

*Corresponding author

\begin{tabular}{|c|c|}
\hline & A B S T R A C T \\
\hline $\begin{array}{l}\text { Ke y w o r d s } \\
\text { Meloidogyne } \\
\text { enterolobii, Psidium } \\
\text { gujava, Psidium } \\
\text { cattleianum, } \\
\text { Histopathology, } \\
\text { India }\end{array}$ & $\begin{array}{l}\text { Root knot nematode Meloidogyne enterolobii cause considerable yield losses in guava. It } \\
\text { is now an emerging menace in guava production. Many authors reported the resistant } \\
\text { nature of Psidium cattleianum against } M \text {. enterolobii. P. cattleianum is a small tree or } \\
\text { shrub with a smooth bark and leaves are obovate elliptic and glabrous. Fruits are round, } \\
\text { having good aroma with sweet taste. The fruits of Psidium gujava are big in size, round, } \\
\text { smooth skin, white or pink flesh, soft, firm, light yellow, pleasant flavor with few seeds. } \\
\text { Mechanisms of resistance against M.enterolobii in guava are studied by taking microtome } \\
\text { sections of infected root tissue of } P \text {. cattleianum and } P \text {. gujava. The results revealed } P \text {. }\end{array}$ \\
\hline Article Info & $\begin{array}{l}\text { cattleianum did not developed any resistant reaction against nematode infection, giant cells } \\
\text { are found to develop normally. The number of giant cell formed is less when compared to }\end{array}$ \\
\hline $\begin{array}{l}\text { Accepted: } \\
\text { 17 April } 2019 \\
\text { Available Online: } \\
10 \text { May } 2019\end{array}$ & $\begin{array}{l}P \text {. gujava. In } P \text {. gujava giant cells were thick walled, multinucleated with rich cytoplasm. } \\
\text { The giant cells in } P \text {. cattleianum appeared to be disrupted and with less dense cytoplasm. } \\
\text { No complex galls or group feeding of nematodes was observed in } P \text {. cattleianum. } \\
\text { Development of nematodes was seems to be hindered. Smaller females are observed in } \\
\text { resistant species when compared to } P \text {. gujava species. }\end{array}$ \\
\hline
\end{tabular}

\section{Introduction}

Guava (Psidium guajava L.) is one of the important commercial fruits in India and known as poor man's fruit. It is the fourth most important fruit after mango, banana and citrus. Guava is native to South America and the West Indies but it is also grown other parts of the tropics and subtropics including
India. The cultivated area of Guava in India 261 MHa with an annual production of $3961 \mathrm{MT}$ with a productivity of $13.9 \mathrm{MT} / \mathrm{Ha}$ (NHB Data Base 2017-18) Likewise the area and production of guava in Tamil Nadu is 9.78Mha and 77.41MT respectively.

Meloidogyne enterolobii is an emerging problem in guava and has been reported from 
Tamil Nadu in recent years and wide spreading now across the Country (Poornima et al., 2016). M. enterolobiiis a species of root knot nematode having a synonym as Meloidogyne mayaguensis, considered that it might have spread from other countries through saplings. Major hosts are Phaseolus vulgaris (bean), Coffea arabica (coffee), Gossypium hirsutum L. (cotton), Solanummelongena (eggplant), Psidium guajava (guava), Solanum quitoense (naranjilla), Carica papaya L. (papaya), Capsicum annuum (pepper), Solanum tuberosum (potato), Glycine max (soybean), Ipomoea batatas (sweet potato), Nicotiana tobacum (tobacco), Lycopersicon esculentum (tomato) and Citrullislanatus (watermelon) (Rammah and Hirschmann, 1988; Brito et al., 2007; Bitencourt and Silva, 2010). Some of the non-hosts include grape fruit, sour orange, garlic, etc.

For the establishment of a successful hostparasite relationship, there must be a compatibility between host plant and nematode during root penetration and feeding site formation is important in order to use resistant plants efficiently in breeding programmes.

The present study has been carried out to know the anatomical changes in root tissues of resistant and susceptible species of guava.

\section{Materials and Methods}

Seeds of $P$. gujava and $P$. cattleianum were obtained from IIHR Bangalore. Pre germinated seeds were sown in a heat sterilized sandy loamy soil in tumbler pots and grown in net house. Egg mass of $M$. enterolobii was collected and kept for hatching in tap water under room temperature, from pure culture of $M$. enterolobii maintained in tomato seedlings at glass house of Horticultural College, Periyakulam and Seven days after hatching, 500 infective juveniles of $M$. enterolobii was inoculated in to each tumbler pots.

After 30 days after inoculation roots from each treatment was uprooted gently washed free of adhering soil. Two to six root galled root segments $(0.5-1.0 \mathrm{~cm})$ per plant were selected, excised and fixed in formalin-aceto alcohol solution (FAA). Then, the root segments were dehydrated in a graded series of ethanol $(35,50,75$ and $100 \%, 1 \mathrm{hr}$ in each series of concentration) infiltrated and embedded in paraffin wax $\left(50-55^{\circ} \mathrm{C}\right)$. Serial Transverse cross sections of thickness $10 \mu \mathrm{m}$ were cut with rotary microtome (Weswox optic MT1090), transferred to glass slides and left for two min to dry. Paraffin wax was removed by soaking the sections xylene and rinsed with ethanol followed by distilled water (Hoppert, 2003). Sections were stained with toluidine blue (Parker et al., 1982) and viewed using light microscope equipped with digital camera (Medline ML105). The presence of females and egg mass was confirmed by staining the roots with acid fuchsin. After staining the roots were observed under stereomicroscope.

\section{Results and Discussion}

\section{Histopathology of Healthy roots}

Histopathology of healthy guava roots revealed the cortex is thin walled and multilayered with circular or polygonal parenchyma cells without intercellular spaces. This is mainly used for transportation of water and salts from the root hairs to the center of root (Abbasi et al., 2013). The cortex, endodermis, and pericycle surrounded by the vascular cylinder (Fig. 1a). Pericycle is the outermost layer of stele and composed single layer of parenchymatous cells without intercellular spaces. Secondary xylem and phloem tissue are arranged in linear chain similar observation was also recorded Aly khan et al., (2017). 


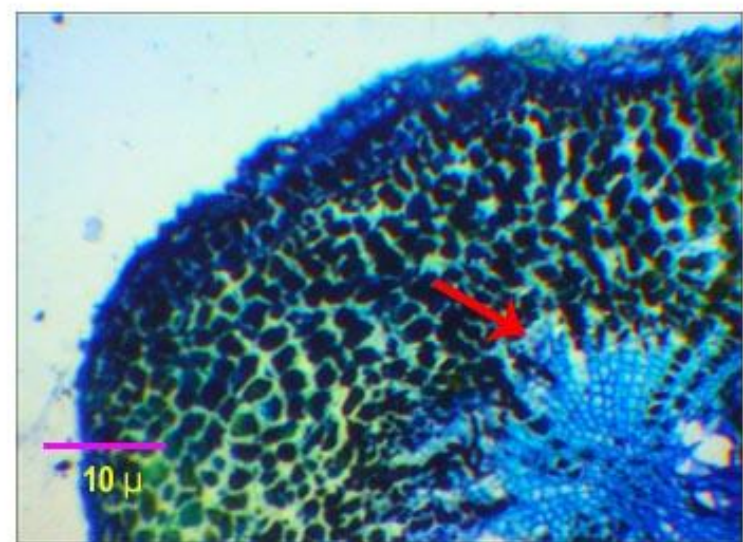

1a

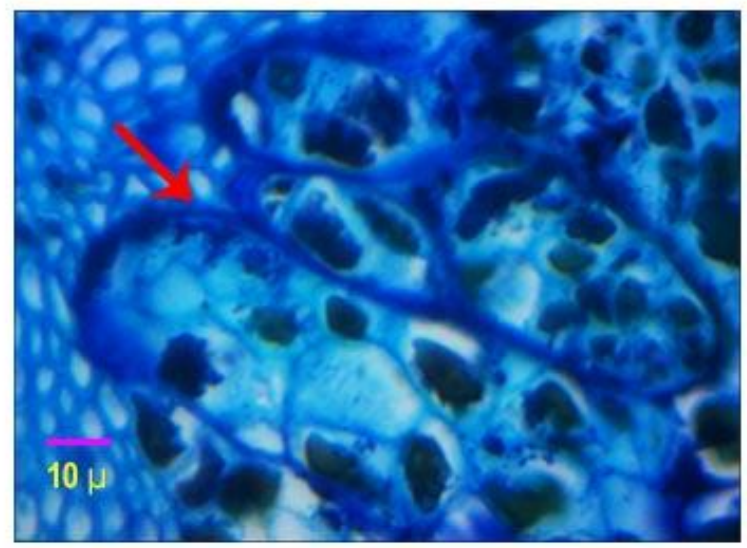

1c

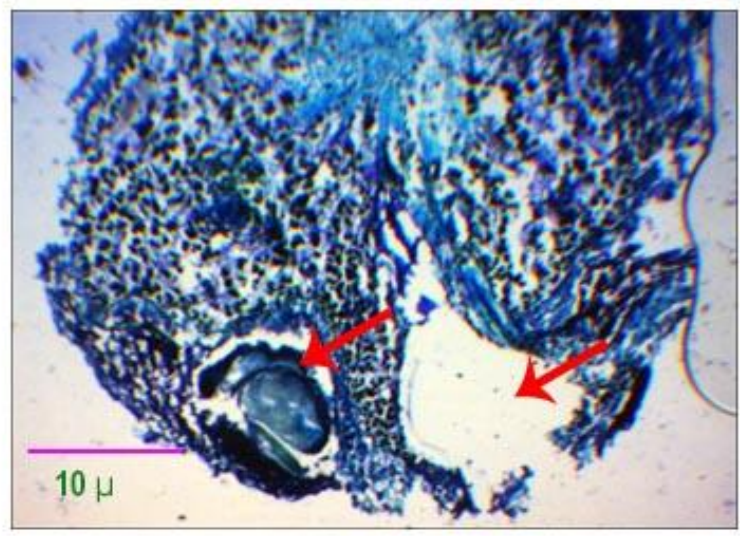

$1 \mathrm{e}$

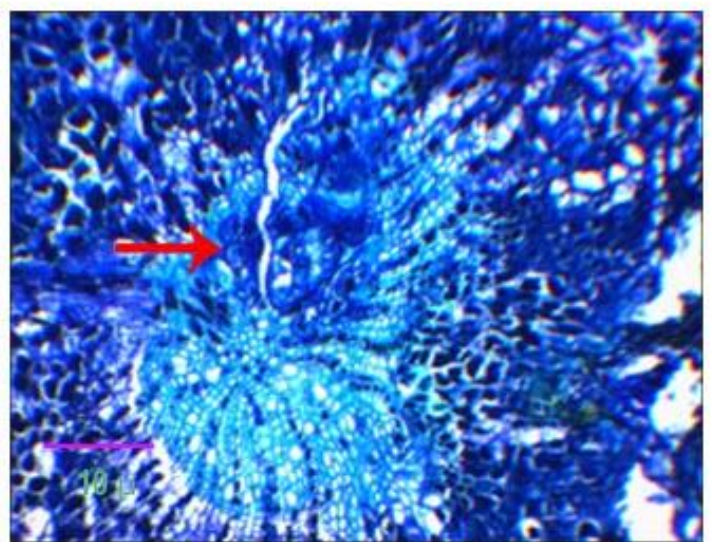

1b

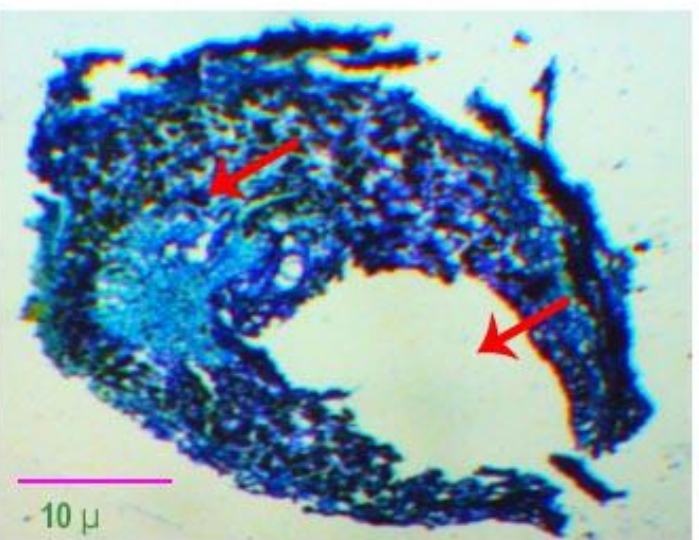

1d

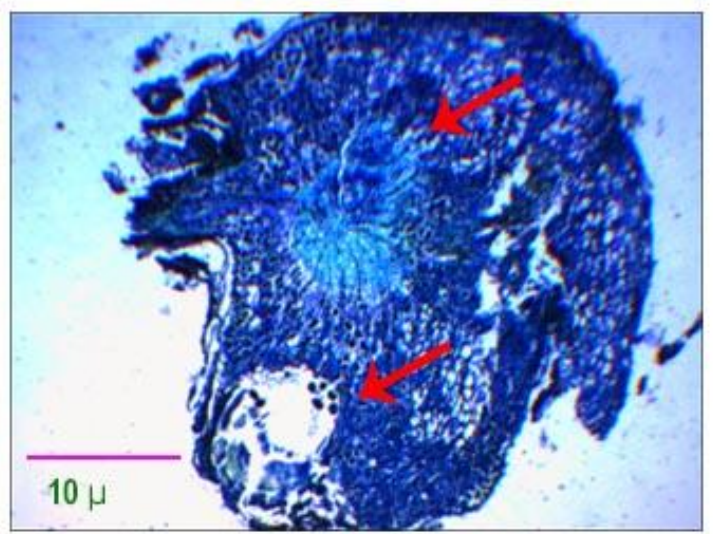

$1 f$

Fig 1. Histopathology of Psidium gujava roots infected with Meloidogyne enterolobii 1a. Healthy cortex with bundle seath containing Xylem and phloem

1b. Giant cells found displacing the xylem and phloem vesseles

1c. Hypertrophied cells with thick wall and rich cytoplasam

1d. Completely displaced bundle seath and ruptured cortex due to enlargment of female 1e. Female nematode and empty space and ruptured cortex due to release of egg mass

1f. Hypertrophied cells and egg mass about to ruptre the cortex 


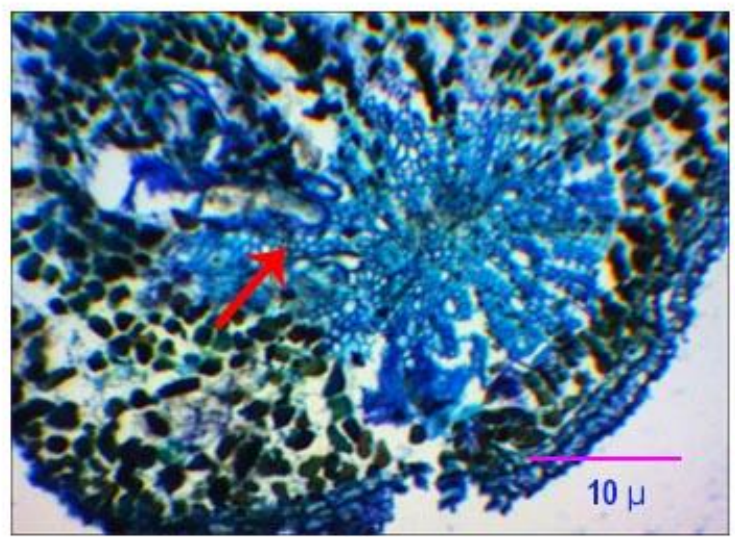

$2 \mathrm{a}$

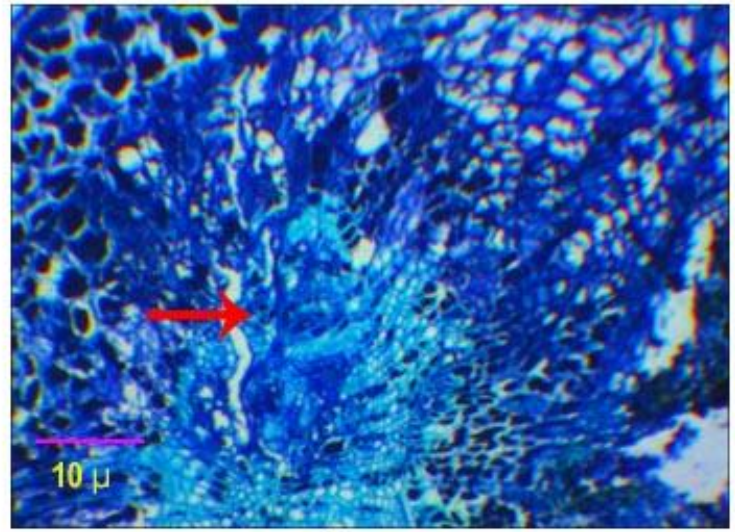

2c

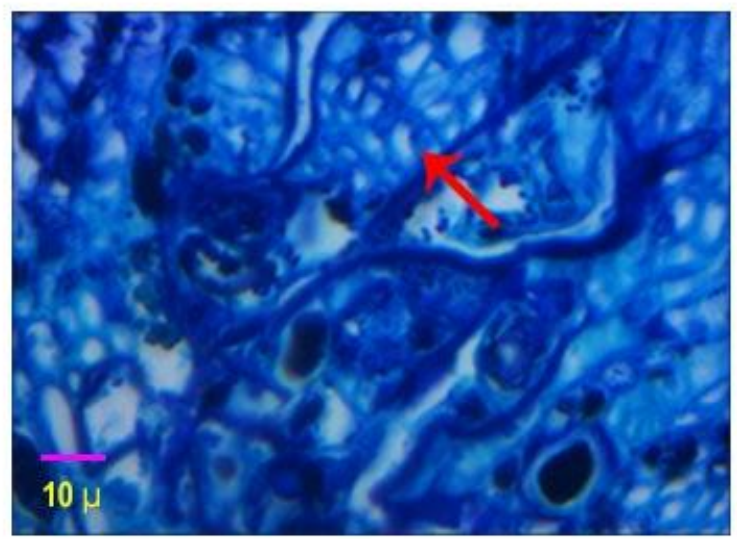

$2 e$

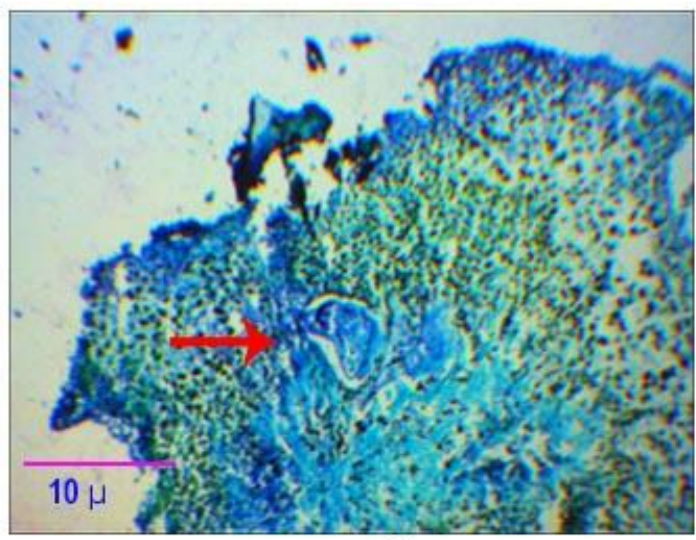

$2 b$

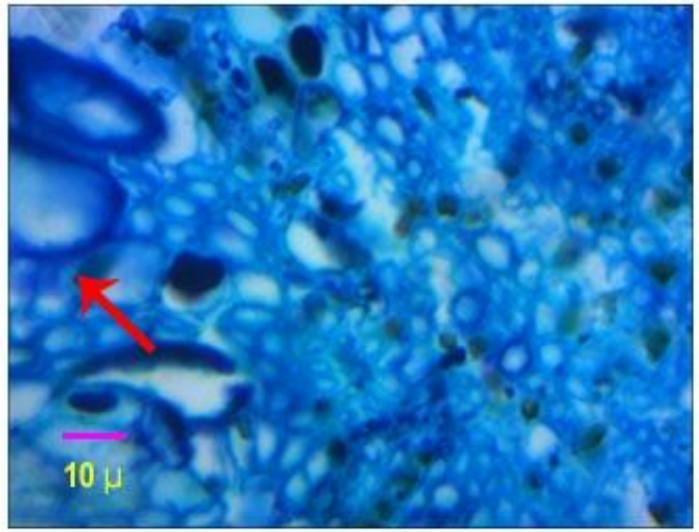

$2 d$

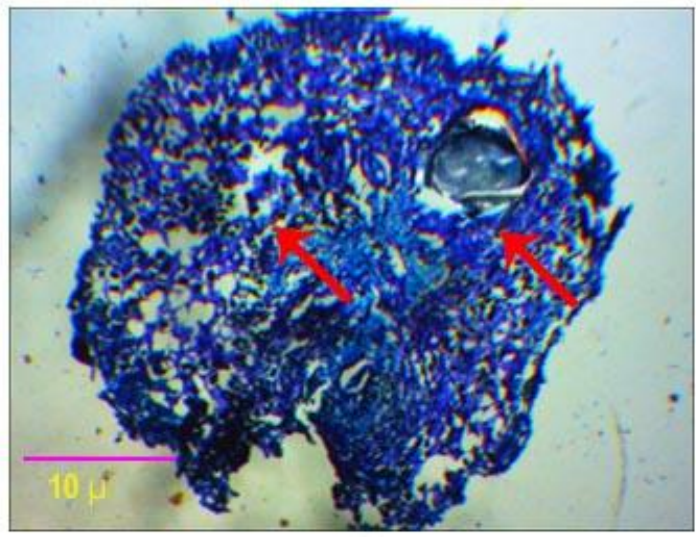

$2 f$

Fig 2. Histopathology of Psidium cattleianum roots infected with Meloidogyne enterolobii 2a. Head of female nematode feeding in giant cell

$2 b$. Shriveled and poorly developed females

2c. Distorted hypertorphied cells

2d. Poorly developed giant cells

2e. Thin walled gaint cells and less cytoplasam

2f. Cortex with more vacuoles and female without egg mass 
Histopathology of $P$. gujava roots infected with M.enterolobii

Anatomical changes caused by the second stage juveniles of $M$. enterolobi revealed the absence of complex galls and group feeding of nematodes (Fig. 1b). Maximum number of giant cells rangebetween4-5only (Fig. 1c). Giant cell dislocate the xylem and phloem cells hindering the transportation of water and nutrients (Fig. 1d). Thickened cell wall with granular cytoplasm and four to ten hypertrophied nuclei and nucleoli in the giant cells (Fig. 1c) was also observed, this is in concurrent with Vovlas (2004) as reported in olive root knot nematode. Hussey and Williamson, 1997 also reported the dislocation of xylem and phloem vessels due to giant cells. Egg masses and females were found to disturb the cortical region of the roots (Fig. 1e). They also distort the root surface leading to rupturing of root cortex (Fig. 1f) which is in accordance with Telizet al., (2007). Fawoe, (1988) reported the deformation of xylem tissues in tomato due to giant cell formation by root knot nematode.

\section{Histopathology of $P$. cattleianum roots infected with $M$. enterolobii}

$P$. cattleianum showed the formation of giant cells (Fig. 2c). This confirms that this species did not provide any host reaction response to nematode penetration (Fig. 2a). There is no complex gall formation and group feeding of nematodes observed. Giant cells were found lesser in number ranges between 2-3 giant cells (Fig. 2d). Poor development of feeding sites and deteriorated giant cells were observed (Fig. 2c) by Alain denis de souse et al., (2016) in some Psidium species. In roots infested with $M$. enterolobii more number of vacuoles (Fig. 2f) were observed it could be a type of resistant reaction of host. Similar observation was observed by Eissa et al., (1988) in resistant host.

Giant cell are small and devoid of any cytoplasmic content (Fig. 2e), wall of the giant cells are also thin. These deformations in the giant cell did not support the development of females (Fig. 2b). Cabasan et al., (2013) reported the degradation of giant cells and host reaction in resistant genotypes of rice infected with root knot nematode. Size of the females was small when compared to P. gujava. Acid fuchsin stained roots showed that there was no egg mass formation. Das et al., (2008) reported that in resistant roots nematode looks shriveled in appearance when compared to susceptible roots as there was no supply of nutrients by the giant cells. But there are healthy giant complexes with rich cytoplasm present in the susceptible roots and also nematode develops to mature female for further infection.

It is concluded in this study, the giant cells in $P$. cattlieianum are found to develop normally with disrupted with less dense cytoplasm and less in number when compared to $P$. gujava. In $P$. gujava giant cells were thick walled, multinucleated with rich cytoplasm. No complex galls or group feeding of nematodes was observed in $P$. cattleianum. No much development of nematodes was seen but smaller females are observed in resistant species when compared to $P$. gujava species.

\section{References}

Abdallah Rammah and Hedwig Hirschmann, 1988. Meloidogyne mayaguensis sp. (Meloidogynidae), a Root-knot Nematode from Puerto Ric, Journal of Nematology, 20(1): 58-69.

Alain denis de sousa, Elvira Mariarégispedrosa, Cláudiaulisses, José Mauro da Cunha e Castro, Juliana Martins Ribeiro, 2016. Penetration, development, and reproduction of Meloidogyne enterolobii on psidium species and induced cellular responses in the roots, Rev. Bras. Frutic., v. 39, n. 2: (e-453)

Alfred J. Parker, Edward F. Haskins and Ingrith Deyrup-Olsen, 1982, Toluidine Blue: A Simple, Effective Stain for Plant Tissues, The American Biology Teacher, Vol. 44, No. 8, pp. 487-489.

Aly Khan, Khalil A. Khanzada, Khatoon, Noorun-Nisa and Shahidshaukat, 2017. 
Histopathology of root-knot nematode (Meloidogyne javanica (treub) chitwood infecting guava seedlings root. Fuuast $J$. Biol., 7(1): 57-60

Fawole, B. 1988. Histopathology of Root-knot Nematode (Meloidogyne incognita) Infection on White Yam (Dioscorea rotundata) Tubers, Journal of Nematology, 20(1): 23-28.

Bitencourt, N. V. and G. S. Silva, 2010. Reproduction of Meloidogyne enterolobii on vegetables, Nematologia brasileira, 34 (3) 181

Eissa, MFM, El-Sherif, MA, Abd-El Gawad, Ismail, AE and El Nagdi, WMA, 2010, Structural diversity of plant parasitic nematodes associated with date palm in Egypt. Pak J Nematol, 27: 351-368.

Johansen, D. A, 1940. Plant microtechnique. McGraw-Hill Book Company. New York.

Ma. Teodora Nadong Cabasan, Arvindkumar, Stéphane Bellafiore and Dirk, 2013. Histopathology of the rice root-knot nematode, Meloidogyne graminicola, on Oryza sativa and $O$. glaberrima, Nematology 16 (2014) 1982, 73-81.

Michael Hoppert, Microscopic techniques in biotechnology, 2003, Weinheim: Wiley$\mathrm{VCH}$.

National Horticulture Board Data base, 2017 18, Pg: 147, 185.

Nicola Vovlas, GraciaLiebnas and Pablo Castillo, 2014.SEM studies on the Mediterranean olive root-knot nematode, Meloidogyne baetica and histopathology on two additional natural hosts, Nematology, Vol. 6(5), 749-754

Poornima, K., Suresh, P., Kalaiarasan, P.,
Subramanian, S., Ramaraju, K. 2016. Root Knot Nematode, Meloidogyne enterolobiiin Guava (Psidium guajava L.) A New Record from India. Madras Agricultural Journal. Vol. 103, Issue 1012, Pp 359-365.

Regaiega. H and N. Horrigue-Raouani, 2018. Histological response of resistant tomato cultivars to infection of virulent Tunisian root-knot nematode (Meloidogyne incognita) populations, Archives of Phytopathology and Plant Protection, 45:17, 2036-2045.

Richard S. Hussey and Valerie M. Williamson, 1998. Agronomy Monograph 36, Plant and Nematode Interactions, 36:87-108.

Sayan Das, Darleen A. DeMason, Jeffrey D. Ehlers, Timothy J. Close and Philip A. Roberts, $2008 . \quad$ Histological characterization of root-knot nematode resistance in cowpea and its relation to reactive oxygen species modulation, Journal of Experimental Botany, Vol. 59, No. 6, pp. 1305-1313.

Swarnsingh, Abbasi and Hisamuddin, 2013. Histopathological response of Lens culinaris roots towards Root knot Nematode. Pakistan Journal of Biological sciences, 16(7): 317-324.

Téliz, D., Landa, B. B., Rapoport, H. F., Pérez Camacho, F., Jiménez-Díaz, R. M., and Castillo, P. 2007. Plant-parasitic nematodes infecting grapevine in southern Spain and susceptible reaction to root-knot nematodes of rootstocks reported as moderately resistant, The American Phytopathological Society Plant, Dis. 91: 1147-1154.

\section{How to cite this article:}

Gummadi Sreekavya, I. Muthuvel, J. Rajangam and Prabhu, S. 2019. Comparative Study on Histopathological Changes caused by Meloidogyne enterolobii in Psidium gujava and Psidium cattleianum Guava Species. Int.J.Curr.Microbiol.App.Sci. 8(05): 2198-2203. doi: https://doi.org/10.20546/ijcmas.2019.805.259 